\title{
What Caused the Winter Drought in Western Nepal during Recent Years?*,+
}

\author{
SHIH-YU WANG \\ Utah Climate Center, and Department of Plants, Soils, and Climate, Utah State University, Logan, Utah \\ JiN-HO YOON \\ Pacific Northwest National Laboratory, Richland, Washington \\ ROBERT R. GILLIES \\ Utah Climate Center, and Department of Plants, Soils, and Climate, Utah State University, Logan, Utah \\ CHANGRAE CHO \\ Utah Climate Center, Utah State University, Logan, Utah
}

(Manuscript received 15 November 2012, in final form 6 May 2013)

\begin{abstract}
Western Nepal has experienced consecutive and worsening winter drought conditions since 2000, culminating in a severe drought episode during 2008/09. In this study, the meteorological conditions and a historical perspective of the winter droughts in western Nepal were analyzed using instrumental records, satellite observations, and climate model simulations. Meteorological diagnosis using atmospheric reanalysis revealed that 1) winter drought in western Nepal is linked to the Arctic Oscillation and its decadal variability, which initiates a tropospheric short-wave train across Eurasia and South Asia; and that 2) the persistent warming of the Indian Ocean likely contributes to the suppression of rainfall through enhanced local Hadley circulation. Simulations from the phase 5 of the Coupled Model Intercomparison Project (CMIP5) sets of historical single-forcing experiments indicated that the increased loading of anthropogenic aerosols is also a compounding factor in the precipitation decline during the later decades. It is therefore conceivable that the recent spells of decadal drought in Nepal are symptomatic of both natural variability and anthropogenic influences. Given the observations that winter precipitation has declined to near zero while groundwater has hardly been replenished, appropriate management of western Nepal's water resources is both critical and necessary.
\end{abstract}

\section{Introduction}

Nepal's agricultural output accounts for roughly $33 \%$ of Nepal's gross domestic product (GDP) and so is heavily reliant upon the country's sources of water. Since Nepal is located at the northernmost edge of the

\footnotetext{
* Supplemental information related to this paper is available at the Journals Online website: http://dx.doi.org/10.1175/JCLI-D12-00800.s1.

${ }^{+}$Utah State University Agricultural Experiment Station Paper Number 8501.
}

Corresponding author address: S.-Y. Simon Wang, 4820 Old Main Hill, Logan, UT 84322.

E-mail: simon.wang@usu.edu
South Asian monsoon system, the monsoon (i.e., wet) season is relatively short (e.g., Saha 2010)-lasting from mid-June until August/September-in contrast to the Indian subcontinent monsoon, while at the same time the "dry" season persists somewhat longer in comparison. However, winter precipitation (i.e., November through February) is not insignificant as it accounts for up to $40 \%$ of Nepal's annual total (Shrestha et al. 2000). Winter precipitation over Nepal is mainly brought about by synoptic weather disturbances that are dynamically different from the monsoon season (e.g., Barlow et al. 2002,2005 ). In the winter season, the westerly jet stream develops over the southern Himalayas and directs the passage of extratropical storms (known as western disturbances) through Nepal. Pronounced interannual variability of winter storm occurrences is correlated with the 
polar/Eurasia teleconnection pattern (Lang and Barros 2004; Li et al. 2008), which links other larger-scale natural climate variabilities, such as the Arctic Oscillation (AO) and the North Atlantic Oscillation (NAO), to the winter climate of Nepal.

In western Nepal, winter monthly precipitation amounts are on the order of $50 \mathrm{~mm}$ or less. The region is particularly reliant on this precipitation for crop production since (i) only $28 \%$ of Nepal's agricultural land is irrigated from groundwater resources (http://www. tradingeconomics.com/nepal/average-precipitation-indepth-mm-per-year-wb-data.html), and (ii) the groundwater replenished through the monsoon is subject to rapid depletion. Moreover, the observed retreat of glacier ice in the Himalayan mountains has also reduced downstream river flows (e.g., Rees and Collins 2006), reducing further the seasonal low flow for snow-fed rivers.

During the winter of 2008/09, western Nepal experienced severe drought conditions that were unprecedented in both scale and severity-precipitation from November 2008 to February 2009 fell below 50\% of average. The severity of the winter drought of 2008/09 was further compounded by the late arrival of the monsoon in 2009, which tends to occur during the warm phase of the El Niño-Southern Oscillation (ENSO; e.g., Fasullo and Webster 2003). On the other hand, a recent study by Wang and Gillies (2013) indicated that the summer monsoon in Nepal is modulated by the Pacific quasi-decadal oscillation (QDO), a global climate anomaly driven by slow fluctuations in the central Pacific SST at the 10-15-yr time scale (Wang et al. 2011). The QDO modulation on the summer monsoon in Nepal results in 2-4 years of below normal (above normal) monsoon conditions during the warm (cool) QDO phases in the central Pacific. Thus, any concurrence of a winter drought with a dry (or late) monsoon will compound the drought severity; such was the case in 2008/09.

There are major human impacts associated with the precipitation regimes of Nepal: since the 1990s, droughts have resulted in food deficits that have caused serious nutritional crises. Of the 75 districts in Nepal, 40 had experienced food deficits. In those districts alone, half of the children under the age of 5 were stunted, $39 \%$ were underweight, and $13 \%$ were severely malnourished (http:// www.wfp.org/news/news-release/winter-drought-worsensfood-insecurity-nepal). By April 2009, wheat and barley production (i.e., the two major winter crops) had decreased by about $50 \%$ in comparison to the previous year. Drought conditions, brought about by variations in the timing and extent of both the wet and dry seasons of Nepal such as had occurred in 2008/09, has clearly exacerbated the food crisis. Hence, it is crucial to examine and understand the climate drivers that lie behind the development of drought in Nepal.

In this study, we focused on the meteorological/ climate conditions that resulted in winter drought over western Nepal with an emphasis toward exploring (i) the mechanism leading to the 2008/09 drought, (ii) any long-term changes in winter droughts, and (iii) the potential for similar droughts in the future. Data sources are discussed in section 2. The overall drought pattern in western Nepal and potential mechanisms are described in sections 3 and 4, respectively. Concluding remarks from the analysis are presented in section 5 .

\section{Data resources}

We utilized multiple sets of observation-based data derived from surface stations, satellites, assimilation systems (i.e., reanalysis) and climate model outputs. The observational datasets are listed in Table 1 including acronyms, full names, descriptions, and spatial resolution. Three rainfall datasets were used: the first was constructed with individual rain gauge observations (GPCC; http://icdc.zmaw.de/gpcc.html?\&L=1), the second was a satellite and rain gauge merged product (GPCP; Adler et al. 2003), and the third was based purely on satellite observed outgoing longwave radiation (i.e., OPI; Janowiak and Xie 1999). Surface air temperature was obtained from the CRU (Mitchell and Jones 2005), and SST was derived from the National Oceanic and Atmospheric Administration (NOAA)'s extended reconstructed SST [ERSST, version 3b (v3b); Smith and Reynolds 2003]. Upper-tropospheric circulation and atmospheric states were derived from the MERRA reanalysis (Rienecker et al. 2011). Additionally, climate oscillation indices (i.e., AO and ENSO) were obtained from the NOAA Earth System Research Laboratory. Finally, terrestrial water storage retrieved from the GRACE twin satellites (level-3 data) was also examined as a surrogate for groundwater storage (Famiglietti et al. 2011).

In an attempt to attribute the cause(s) of the observed changes in precipitation over Nepal, we examined historical simulations produced for phase 5 of the Coupled Model Intercomparison Project (CMIP5; Taylor et al. 2012) and used two sets of historical single-forcing experiments that were driven by (i) aerosol forcing only (aerosol) and (ii) greenhouse gas forcing only (GHG). Each experiment produced a number of ensemble members initialized from long stable preindustrial (1850) control settings up to 2005. Only models that produced two or more members were analyzed; their acronyms, full names, and descriptions are provided in Table 2. 
TABLE 1. Datasets utilized in this study.

\begin{tabular}{|c|c|c|}
\hline Dataset & Full name & Description \\
\hline $\mathrm{CRU}\left(T_{S}\right)$ & Climate Research Unit surface temperature & $\begin{array}{l}\text { CRUTEM4; database of gridded historical near-surface air } \\
\text { temperature anomalies over land at a } 5.0^{\circ} \text { resolution. }\end{array}$ \\
\hline MERRA & $\begin{array}{l}\text { Modern-Era Retrospective Analysis for } \\
\text { Research and Applications }\end{array}$ & $\begin{array}{l}\text { The latest global atmospheric reanalysis produced by the } \\
\text { National Aeronautics and Space Administration (NASA) at } \\
\text { a } 1.5^{\circ} \text { resolution. }\end{array}$ \\
\hline GPCP & Global Precipitation Climatology Project & $\begin{array}{l}\text { Merged analysis from gauges, geostationary and low-orbit } \\
\text { satellite observations at a } 2.5^{\circ} \text { resolution (version } 2 \text { ). }\end{array}$ \\
\hline GRACE & Gravity Recovery And Climate Experiment & $\begin{array}{l}\text { NASA twin satellites launched in March } 2002 \text { to measure } \\
\text { Earth's gravity field; we used the GRACE level-3 data } \\
\text { products at a } 2.5^{\circ} \text { resolution. }\end{array}$ \\
\hline OLR & Outgoing longwave radiation & $\begin{array}{l}\text { Measurements taken from NOAA series polar orbiting } \\
\text { satellites at a } 2.5^{\circ} \text { resolution. }\end{array}$ \\
\hline OPI & OLR precipitation index & $\begin{array}{l}\text { Precipitation estimates purely from a satellite algorithm at a } \\
2.5^{\circ} \text { resolution. }\end{array}$ \\
\hline SST & Sea surface temperature & $\begin{array}{l}\text { Extended reconstructed sea surface temperature at a } 2.0^{\circ} \\
\text { resolution. }\end{array}$ \\
\hline $\mathrm{AO}$ & Arctic Oscillation & $\begin{array}{l}\text { Operational monthly index produced by the NOAA Climate } \\
\text { Prediction Center. }\end{array}$ \\
\hline ENSO (Niño-3.4) & $\begin{array}{l}\text { El Niño-Southern Oscillation defined by } \\
\text { sea surface temperature anomalies } \\
\text { over } 5^{\circ} \mathrm{S}-5^{\circ} \mathrm{N}, 170^{\circ}-120^{\circ} \mathrm{W}\end{array}$ & $\begin{array}{l}\text { Operational monthly index produced by the NOAA Climate } \\
\text { Prediction Center (available at http://www.esrl.noaa.gov/psd/ } \\
\text { data/climateindices/list/). }\end{array}$ \\
\hline
\end{tabular}

\section{Indications of drought}

\section{a. Precipitation declines}

The extent of the 2008/09 winter drought over western Nepal was first analyzed by the examination of the geographical distribution of precipitation anomalies. The difference in GPCC precipitation (November-February) between the decades of 2001-10 and 1991-2000 is illustrated in Fig. 1a. During the latter decade, a pronounced precipitation deficit is manifest over the western region of Nepal-centered in the Terai (plains) and stretching farther into the southern Himalayan foothills. The time series of winter precipitation (Fig. 1b; NovemberFebruary), averaged over a $5^{\circ}$ longitude $\times 2.5^{\circ}$ latitude region centered at western Nepal (for the domain outlined in Fig. 1a), shows that a somewhat persistent downward trend has occurred since 1995. The precipitation trend is further illustrated by a 6 -yr moving average (black line aligned to the end year). It appears that the 2008/09 drought is not just a single event; rather, it is embedded within three consecutive dry winters since 2007. Perhaps of more significance is the fact that the 2008/09 drought is part of a decade-long drying trend since 2000. Moreover, it is worth mentioning that of the five winter droughts defined by GPCC data (as monthly precipitation lower than $10 \mathrm{~mm}$ including 1966/67, 2005/ 06, 2007/08, 2008/09, and 2009/10), four have occurred after 2005.

Since the quality and quantity of station records that formed the gridded data in this region might be questionable (Ghosh et al. 2009), we also analyzed GPCP data that blend both satellite rainfall retrieval and gauge data. It was found that, as was the case for the rain gauge plot, a consistent downward trend in precipitation is indeed evident (Fig. 1c) and likewise indicates five winter droughts have taken place since 2000. A third verification involved the examination of OPI (i.e., one that is made only with a satellite observation based upon infrared band measurements). The winter OPI time series shown in Fig. 1d similarly confirms the striking but a remarkably steeper decline in precipitation in comparison to the GPCC and GPCP data. It is noteworthy that OLR (used for deriving the OPI) in mountainous regions like Nepal may be contaminated by signals of warming surface temperature and decreasing snow albedo. Nonetheless, the consistent variations and recent downtrends of these three independent precipitation observations (Figs. 1b-d) reinforce a situation on the ground of persistent drought conditions in western Nepal over the last decade.

\section{b. Groundwater declines}

Rodell et al. (2009) related the liquid water equivalent thickness (LWET) observed by GRACE with the terrestrial water storage (TWS) in northwestern India and found a steep decline in the region's groundwater from 2002 to 2008 (equivalent to a net loss of $109 \mathrm{~km}^{3}$ of water). In line with Rodell et al. (2009)'s GRACE analysis, we extended the regional coverage to include western Nepal. The GRACE-derived result in LWET 
TABLE 2. CMIP5 models analyzed with model names expanded.

\begin{tabular}{|c|c|c|}
\hline Model & Full name & Institution \\
\hline CESM1 & Community Earth System Model, version 1 & National Center for Atmospheric Research (NCAR) \\
\hline CanESM2 & Canadian Second Generation Earth System Model & $\begin{array}{l}\text { Canadian Centre for Climate Modelling and } \\
\text { Analysis (CCCma) }\end{array}$ \\
\hline CCSM4 & Community Climate System Model, version 4 & National Center for Atmospheric Research (NCAR) \\
\hline CNRM-CM5 & $\begin{array}{l}\text { Centre National de Recherches Météorologiques } \\
\text { Coupled Global Climate Model, version } 5\end{array}$ & $\begin{array}{l}\text { Centre National de Recherches Météorologiques } \\
\text { (CNRM)/Centre Européen de Recherche et de } \\
\text { Formation Avancées en Calcul Scientifique } \\
\text { (CERFACS) }\end{array}$ \\
\hline GFDL CM3 & $\begin{array}{l}\text { Geophysical Fluid Dynamics Laboratory Climate } \\
\text { Model, version } 3\end{array}$ & NOAA/Geophysical Fluid Dynamics Laboratory (GFDL) \\
\hline CSIRO & $\begin{array}{l}\text { Commonwealth Scientific and Industrial } \\
\text { Research Organization }\end{array}$ & $\begin{array}{l}\text { Commonwealth Scientific and Industrial Research } \\
\text { Organization/Queensland Climate Change Centre of } \\
\text { Excellence (CSIRO-QCCCE) }\end{array}$ \\
\hline FGOALS & Flexible Global Ocean-Atmosphere-Land System & $\begin{array}{l}\text { Institute of Atmospheric Physics (IAP), Chinese } \\
\text { Academy of Sciences }\end{array}$ \\
\hline GISS-E2 & $\begin{array}{l}\text { Goddard Institute for Space Studies Model E, } \\
\text { version } 2\end{array}$ & NASA Goddard Institute for Space Studies (GISS) \\
\hline IPSL-CM5 & $\begin{array}{l}\text { Institut Pierre Simon Laplace Coupled Model, } \\
\text { version } 5\end{array}$ & Institut Pierre-Simon Laplace (IPSL) \\
\hline NorESM1 & Norwegian Earth System Model, version 1 & Norwegian Climate Centre (NCC) \\
\hline
\end{tabular}

shows a widespread decline in the Indo-Gangetic Plain and Nepal (see Fig. 2a inset that portrays the spatial distribution of the linear trend); this analysis indicates a marked reduction in groundwater storage over the past decade. Rodell et al. (2009) attributed the loss of groundwater over northern India to unsustainable water consumption for irrigation and other anthropogenic purposes. However, in western Nepal where winter precipitation has decreased substantively in recent years, a groundwater decline as severe as that shown in Fig. 2a from 2005 onward would suggest that water recharge through monsoon precipitation is becoming inadequate to compensate for accelerated discharge/withdrawal during the dry season.

\section{c. Temperature increases}

In western Nepal, air temperature has steadily warmed by almost $1^{\circ} \mathrm{C}$ since 1990 , as is shown in Fig. 2b. Increased air temperature will, to first-order approximation, act to enhance evapotranspiration, which could exacerbate any drought that has already been induced by any precipitation decline. Accompanying the surface temperature increase, the SST in the tropical Indian Ocean (averaged within $20^{\circ} \mathrm{S}-20^{\circ} \mathrm{N}, 45^{\circ}-100^{\circ} \mathrm{E}$ ) has likewise increased since 1975 but only by about $0.4^{\circ} \mathrm{C}$ (Fig. 2b). As noted in Hoerling and Kumar (2003), SST warming likely enhances upward motion in the tropics and subsequently reinforces subsidence in the subtropics, including Nepal; this process is discussed further in section 4c. In addition to warming in the tropical Indian Ocean, an aerosol-induced cooling of near-shore
SST surrounding the Indian subcontinent can suppress the development of the South Asian summer monsoon (Chung and Ramanathan 2006; Ganguly et al. 2012; Ramanathan et al. 2005); this thermal contrast is caused by rapid and massive emissions of pollutants, mainly $\mathrm{SO}_{2}$ from fossil fuel burning. It is therefore possible that aerosol-induced cooling and land-atmosphere feedback processes act to suppress the winter precipitation; this will be considered further in section $4 \mathrm{~d}$.

\section{Mechanisms}

\section{a. Interannual variation}

The atmospheric circulation patterns associated with the 2008/09 drought were analyzed by examining the 500-mb wind anomalies from the 1980-2010 climatology, averaged over the November-February season. The wind anomalies are shown in Fig. 3a as streamlines overlaid with the GPCC precipitation anomalies. A robust anticyclonic cell appears over the Indian subcontinent and the Bay of Bengal. The anticyclone is embedded within a series of short waves (i.e., alternating cyclonic/anticyclonic cells) that have their origin in Europe-referred to as the Eurasian wave train (e.g., Ding and Wang 2007) and are indicated by the red arrow line. The Eurasian wave train has been shown to link winter climate anomalies in Europe (such as snow cover) with those in northern India and Nepal (Lang and Barros 2004; Li et al. 2008). Subsequently, in order to confine our analysis to interannual variability, we 
(a) 10-yr precipitation diff.: Nov-Feb

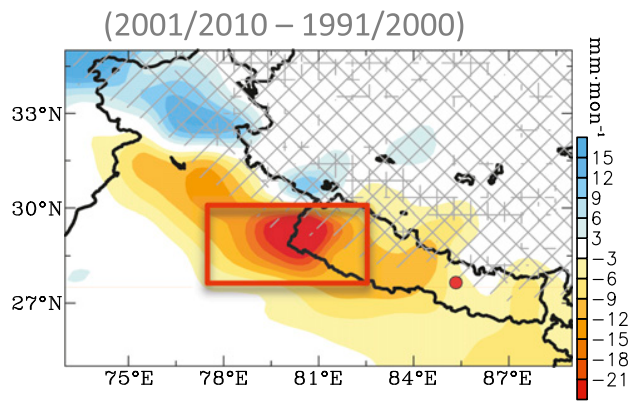

(b) GPCC (rain gauge)
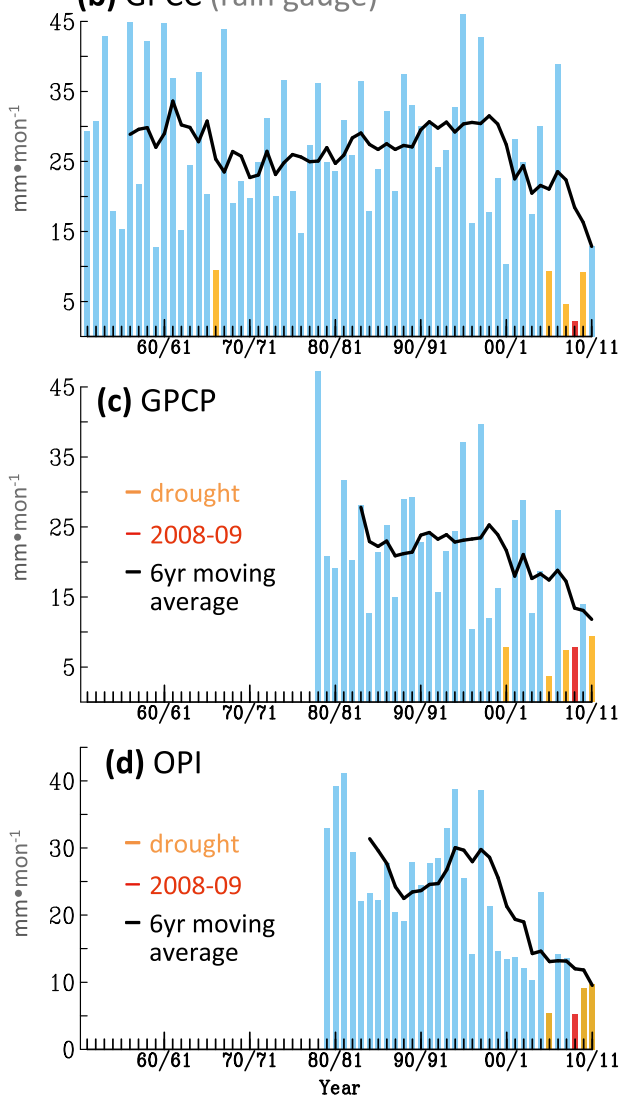

FIG. 1. (a) Winter precipitation differences between the two decades derived using GPCC (station based) data and winter precipitation evolution in western Nepal within the domain shown in (a) based on (b) GPCC, (c) GPCP (satellite gauge merged), and (d) OPI (satellite only). In (b)-(d), the black line indicates the 6-yr moving average; the orange bar indicates drought defined as precipitation less than $10 \mathrm{~mm}$; and the red bar indicates the 2008/09 drought.

removed the linear trend of the 1980-2010 period and calculated the residual wind anomalies. These are plotted in Fig. $3 \mathrm{~b}$ and reveal a similar circulation pattern as was the case in Fig. 3a but feature a broader anticyclone over India. The Eurasian wave train still remains evident in this residual circulation pattern, suggesting that the large-scale circulation anomalies leading to the 2008/09 (a) GRACE Liquid Water Equivalent Thickness
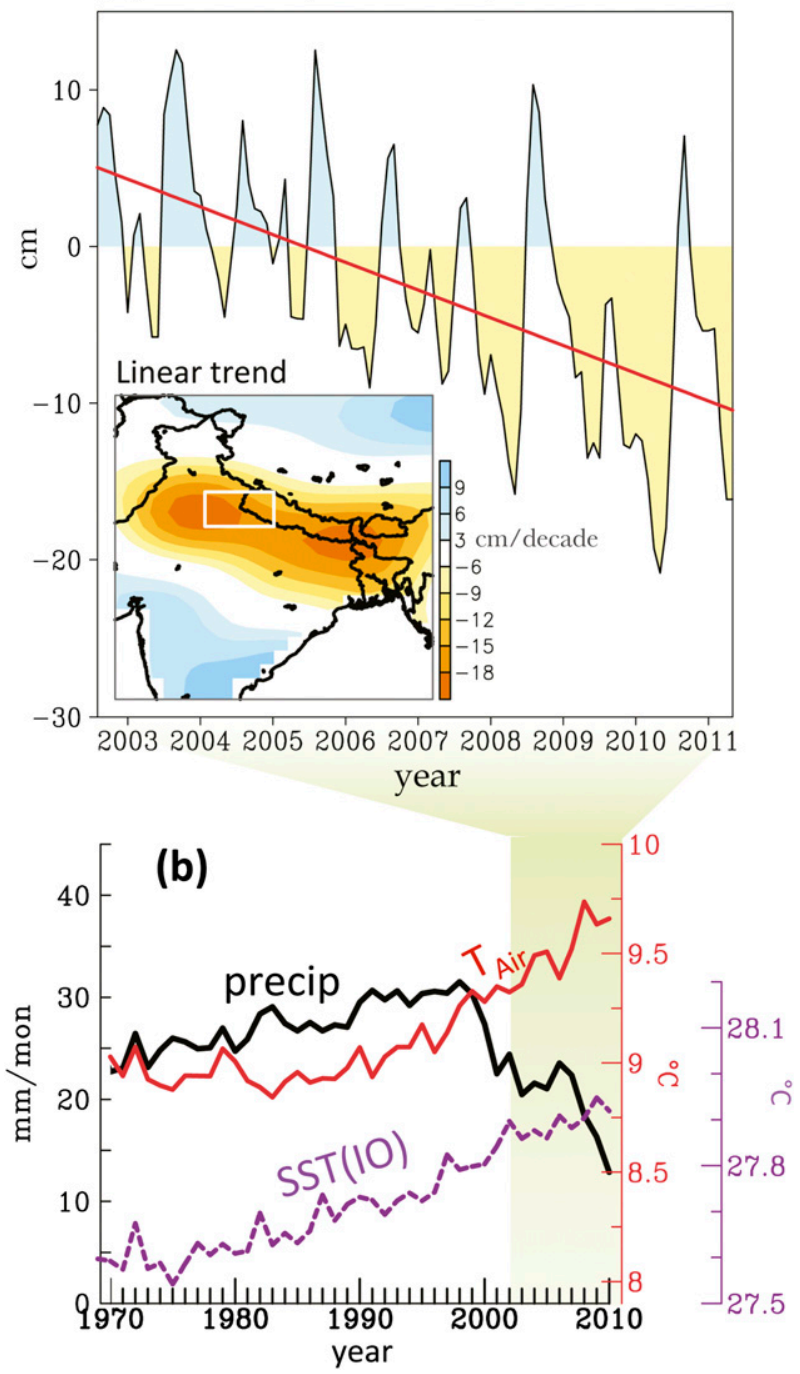

FIG. 2. (a) Groundwater estimates over western Nepal (GRACE satellite observation) overlaid with the map of the linear trend (inset), where the domain for the time series is indicated by a white box. (b) Winter precipitation 6-yr moving average in western Nepal as in Fig. 1b overlaid with air temperature (red line) and SST of the Indian Ocean (IO; purple dashed line) in the same season.

drought may be part of a long-term change associated with this wave train.

In search of the mechanism leading to the circulation changes, an EOF analysis was applied to the 500-mb streamfunction $\psi_{500}$ during the November-February season from 1980 to 2011. The EOF analysis depicts two modes, EOF1 (Fig. 4a) and EOF2 (Fig. 4c), which together explain $60 \%$ of the variance. EOF1 depicts a continental-scale cyclonic circulation extending from Africa to East Asia, covering India and Nepal. Marked interannual variability is revealed in the first principal 
(a) $\Delta \mathbf{V}(500 \mathrm{mb}), \Delta \mathrm{P}: 2008 / 09 \mathrm{NDJF}$ from $1980-2010$

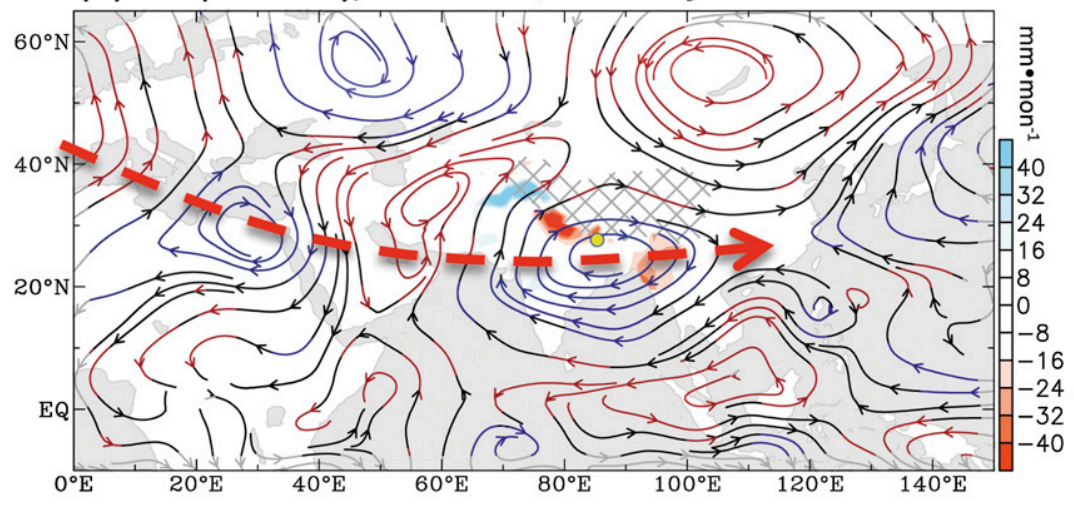

(b) $\Delta \mathbf{V}(500 \mathrm{mb}), \Delta \mathrm{P}: 2008 / 09 \mathrm{NDJF}$ detrended

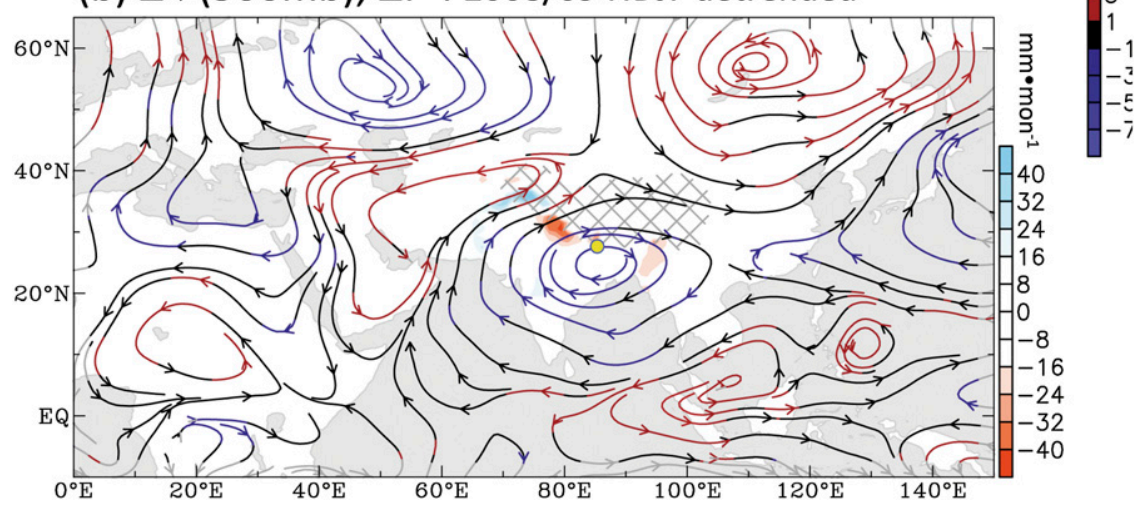

FIG. 3. (a) Departure of 500-mb winds of the 2008/09 winter from the 1980-2010 climatology, superimposed with the precipitation anomalies. The streamlines are colored with the values of relative vorticity. The hatched area indicates topography over $4000 \mathrm{~m}$. (b) As in (a), but for 1980 2010 with the linear trend removed in order to focus on the interannual component of the variation.

component (PC1; Fig. 4b) and it corresponds closely with the Niño-3.4 index, with a high correlation coefficient (0.78). Linear regression of precipitation anomalies with PC1 (Fig. 4a) indicates wet conditions beneath the cyclonic circulation with dry conditions in Indochina and the Maritime Continent. However, only weak to nonexistent precipitation anomalies appear over Nepal; this result is in agreement with the known El Niño influence on Asian precipitation in general (e.g., Ropelewski and Halpert 1987).

By comparison, EOF2 (Fig. 4c) depicts a series of short waves similar to the Eurasian wave train, while western Nepal is juxtaposed between a cyclonic cell to the west and an anticyclonic cell to the east. Significant negative precipitation anomalies (i.e., drying) are observed in Nepal. As shown in PC2 (Fig. 4d), the EOF2 circulation corresponds well with the negative phase of the $\mathrm{AO}$, given its significant correlation coefficient with PC2 (0.83). Noteworthy also is that PC2 correlates significantly with the NAO $(0.48 ; p<0.01)$, but the correlation is distinctly lower than that with the AO.
Moreover, there exists a significant trend in the AO of stronger negative-phase events since the late 1980s; this may correspond to the tendency that the EOF2 wave train has occurred more frequently in recent years. Such an inference is supported by an EOF analysis conducted on the low-pass-filtered $\psi_{500}$ with $6 \mathrm{yr}$ (not shown). EOF2 of the filtered $\psi_{500}$ depicts a similar wave train pattern with a tendency toward the negative AO and explains about $25 \%$ of the unfiltered variance.

The dynamical process associated with the AO (EOF2) wave train was examined next. We first computed the transient activity of synoptic waves by bandpass filtering daily 500-hPa meridional winds $v$ with 2-9 days during the November-February season (following, e.g., Lau and Nath 1991). The root-mean-square of the filtered $v$ was then calculated, denoted as $\operatorname{RMS}\left(v^{\prime}\right)$ and representing the atmospheric transient activity; this $\operatorname{RMS}\left(v^{\prime}\right)$ was regressed with PC2 over the 1980-2011 period and is shown in Fig. 5a overlaid with the climatological 500-hPa winds. The purpose in doing so was to examine whether and to what extent the activity of 

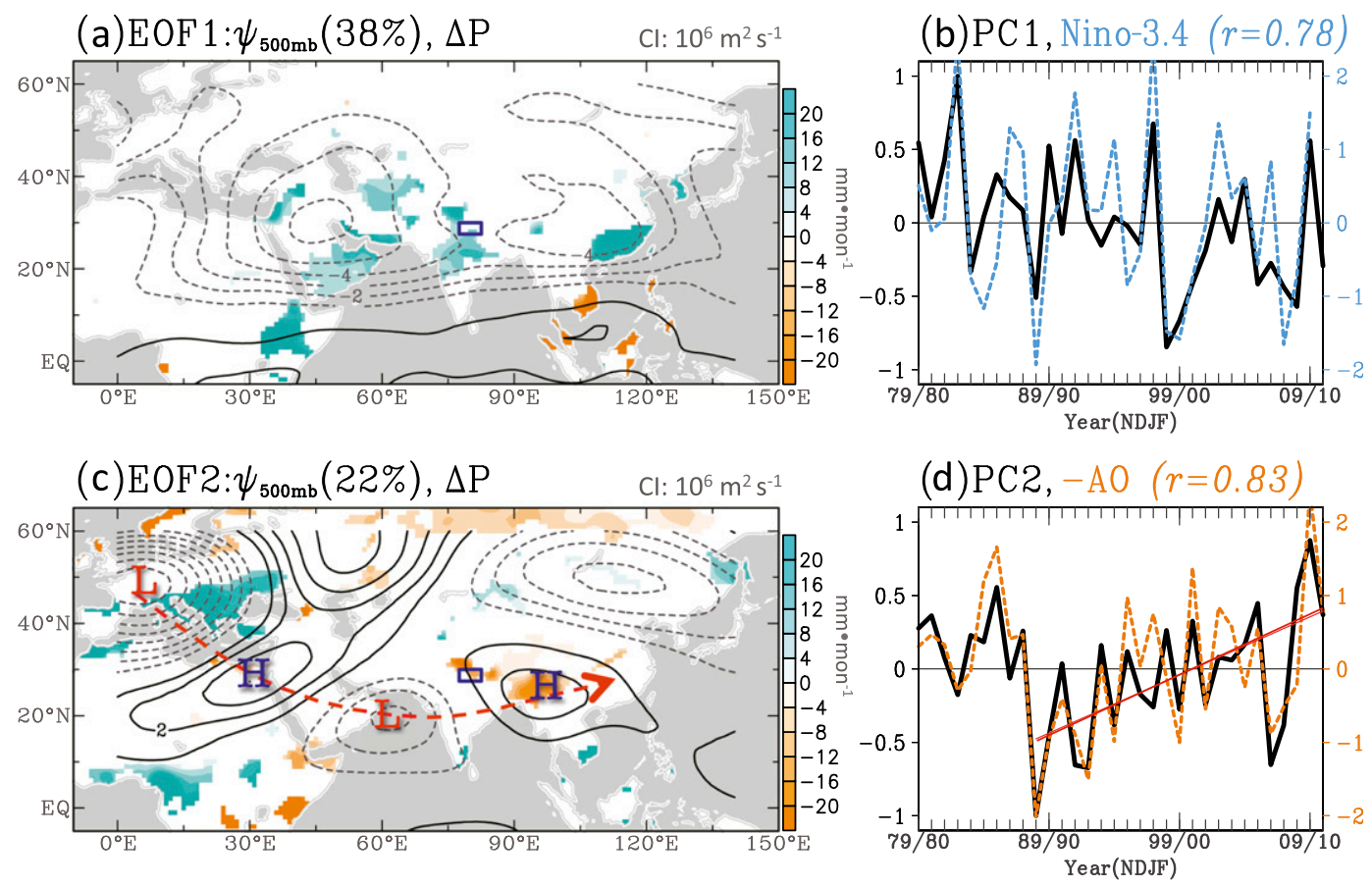

FIG. 4. The leading two EOFs and PCs of the 500-mb streamfunction $\psi_{500}$ from the winter of 1979/80 to 2010/11. The precipitation regressions of the PC time series are overlaid with the EOFs as shadings. (a),(c) The H and L symbols indicate anticyclonic and cyclonic anomalies, respectively. Western Nepal is outlined as a blue box. (b) The Niño-3.4 index is superimposed with PC1, while (d) the inverted AO index is superimposed with PC2; their correlation coefficients are indicated at the top right. The linear trend of the AO index for the 1988-2011 period is added in (d) as a red line; this trend is significant at the $99 \%$ confidence interval per Student's $t$ test.

synoptic waves is modulated by the AO-associated wave train. It appears that the activity of synoptic waves is substantially reduced over Scandinavia and eastern Europe during negative AO phases and is accompanied by increased transient activity in North Africa; this may suggest a reduction in synoptic waves propagating downstream toward western Nepal. Although the 500-hPa RMS $\left(v^{\prime}\right)$ lacks substantial anomalies in the vicinity of Nepal, at $850 \mathrm{hPa}$ (not shown) a negative anomaly appeared over Afghanistan and Pakistan, suggesting such a reduction in synoptic activity. Consequently, we further constructed the latitudinal cross section of vertical velocity and divergent wind anomalies regressed from PC2, producing the mass-flux circulation across western Nepal $\left(77^{\circ}-83^{\circ} \mathrm{E}\right)$, which is shown in Fig. 5b. A descending branch of the mass fluxes appears over Nepal, and this is coupled with the local Hadley circulation to the south (with subtropical ascent and equatorial decent of the air). The upslope flows to the north of the Himalayas might also induce downslope subsidence over Nepal. Furthermore, the impact of this mass-flux circulation on precipitation was examined through regression of the precipitation percentile (Fig. 5c; using GPCP). The change in the precipitation percentile shows decreased rainfall in Nepal underneath the descending branch, accompanied by increased rainfall near $10^{\circ} \mathrm{N}$ with the ascending branch.

\section{b. Decadal variation}

Given the negative tendency of the AO since the late 1980s, the interannual variability of rainfall over western Nepal may be further modulated by decadal variability. However, long-term trends in the AO have been under debate regarding its cause [i.e., atmospheric internal processes or influence of anthropogenic forcing; Delworth and Dixon (2000); Feldstein (2002); Choi et al. (2010)]. To examine these further, we expanded the analysis domain to cover the Atlantic Ocean. Plotted in Fig. $6 \mathrm{a}$ are the differences of the $500-\mathrm{mb}$ streamlines between the 2001-10 and 1991-2000 periods. The Eurasian wave train stands out and seems to be linked to a meridionally oriented circulation dipole over the North Atlantic (indicated by $\mathrm{L} / \mathrm{H}$ on the cyclonic/ anticyclonic cells). Next, we tried to identify the energy source region associated with this wave train pattern by computing the wave activity flux, which depicts the forcing source for stationary wave anomalies (namely the Rossby wave source; Hoskins and Ambrizzi 1993). 


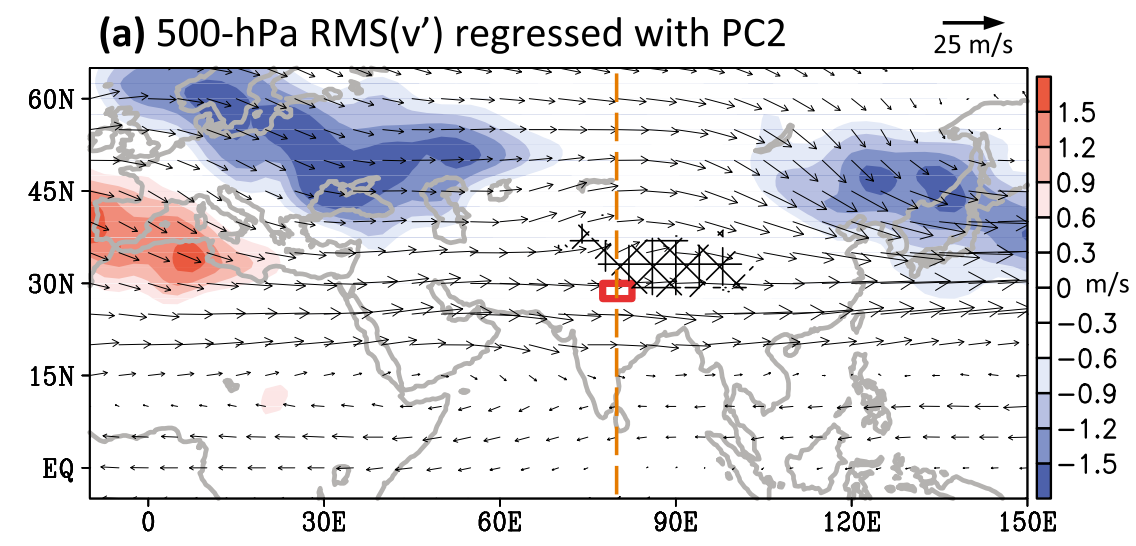

(b) Mass-flux circulation regressed with PC2

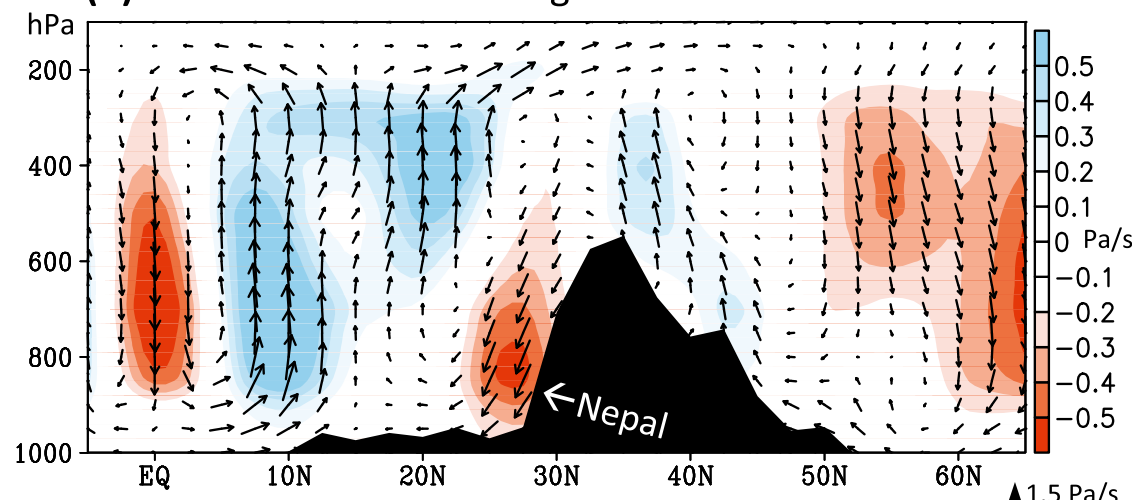

(c) Precipitation percentile regressed with PC2

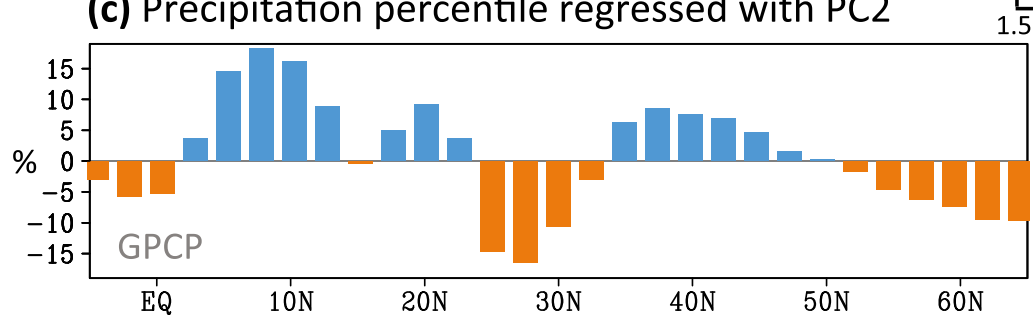

FIG. 5. (a) The 500-hPa transient activity RMS $\left(v^{\prime}\right)$ regressed upon PC2 of Fig. $4 d$ as shading, overlaid with the climatological wind vectors. Hatched area indicates the Tibetan Plateau above $4500 \mathrm{~m}$. Red box indicates western Nepal. (b) Mass-flux circulation in terms of the vertical velocity $-\omega$ and meridional divergent wind $v_{D}$ across $77^{\circ}-83^{\circ} \mathrm{E}$ regressed upon $\mathrm{PC} 2$. Shading indicates $-\omega$ and black area represents the topography. (c) Precipitation percentile across $77^{\circ}-83^{\circ} \mathrm{E}$ regressed upon PC2 using the GPCP data.

Takaya and Nakamura (2001) formulated the wave activity flux $\mathbf{W}$ for stationary and migratory waves as

$$
\mathbf{W}=\frac{1}{2|\mathbf{U}|}\left[\begin{array}{l}
u\left(\psi_{x}^{2}-\psi \psi_{x x}\right)+v\left(\psi_{x} \psi_{y}-\psi \psi_{x y}\right) \\
u\left(\psi_{x} \psi_{y}-\psi \psi_{x y}\right)+v\left(\psi_{y}^{2}-\psi \psi_{y y}\right)
\end{array}\right],
$$

where $\psi$ is the perturbation streamfunction, $\mathbf{U}$ is the two-dimensional November-February mean flow of the wind components $(u, v)$, and where subscripts represent partial derivatives. Equation (1) is an extension of the Eliassen-Palm wave flux (Plumb 1985) derived for the zonally averaged basic flows. The direction of the wave activity flux vector produced from Eq. (1) indicates the group velocity of Rossby waves. The calculation of Eq. (1) is independent of temporal averaging and as such is suitable for analyzing wave activity in the decadal time scale.

As is indicated in Fig. 6a, the flow of the wave activity flux (vectors) implies that the high-latitude North Atlantic is the major Rossby wave source with the energy propagating downstream along two routes. One follows a route along eastern Europe into central Siberia (e.g., Wang and Yasunari 1994; Nakamura et al. 2010), while 
(a) $\Delta \mathrm{V}(500 \mathrm{mb}), \Delta \mathrm{SST}$, wave-flux

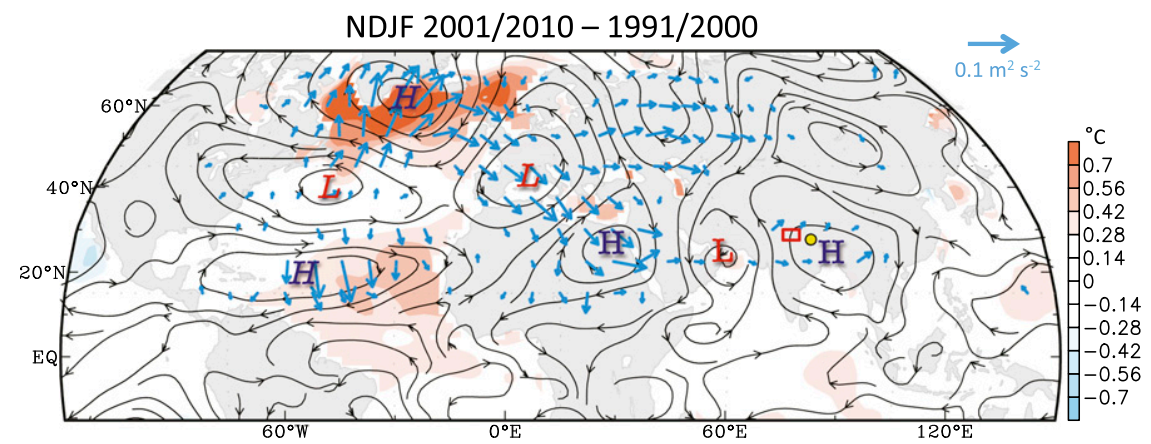

(b) $\Delta \Psi(500 \mathrm{mb}), \Delta \psi_{\mathrm{E}}$ NDJF -AO composite, detrended

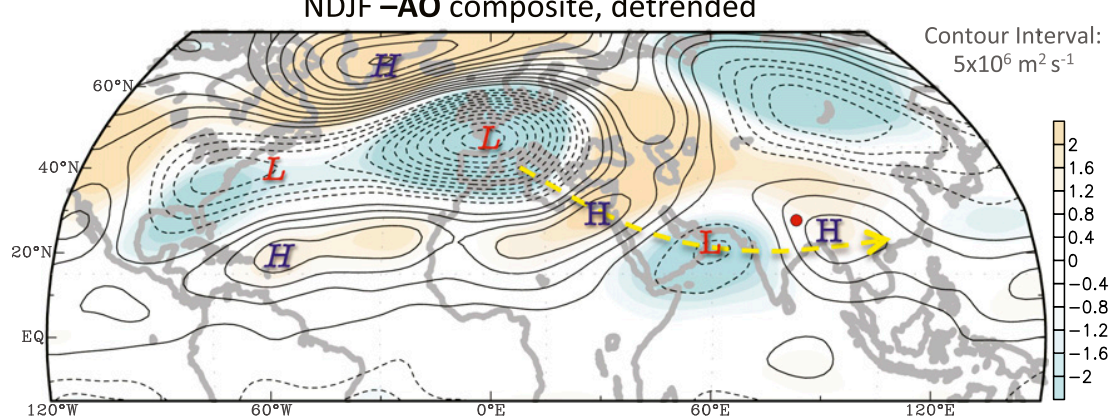

FIG. 6. (a) Difference of 500-mb streamlines between the 2001-10 and 1991-2000 periods, superimposed with the SST anomalies (shadings) and the wave activity flux (vectors). The H/L symbols indicate anticyclonic/cyclonic anomalies, while the red box indicates western Nepal. (b) Composite differences of the 500-mb streamfunction between negative AO years (centered in January 1985, 1986, 1996, 1998, 2001, 2003, 2009, and 2010) and positive AO years (1983, 1989, 1990, 1992, 1993, 1995, 2007, and 2008), with the linear trend removed. The eddy streamfunction is overlaid as shadings. Nepal's capital city Kathmandu is indicated as a yellow or red dot.

the other, the more pronounced route, passes over the Mediterranean into northeast Africa and then the Arabian Sea; there, the local cyclonic anomaly appears to induce the wave activity flux farther toward the Bay of Bengal. The latter wave train resembles that observed during the premonsoon season that was proposed to be induced by Eurasian snow cover anomalies (Bamzai and Shukla 1999; Ding and Wang 2007). In the North Atlantic around Greenland, the SST anomalies exhibit substantial warming, likely a result of increased solar radiation absorbed beneath the anticyclonic anomaly. Another noticeable SST warming appears in the subtropical Atlantic; this warming may induce the circulation anomalies over the tropics (Yoon and Zeng 2010), but the wave activity flux analysis shown here suggests that the tropical anticyclonic cell does not contribute to the Eurasian wave train that eventually influences Nepal.

The decadal change of the $500-\mathrm{mb}$ circulations (Fig. 6a) resembles both the EOF2 pattern in Fig. 4c and the 2008/09 drought situation in Fig. 3a. The spatial resemblance suggests that the AO influence may have changed over the past two decades, as was suggested from its linear trend in Fig. 4d. To further examine this possibility, we conducted a composite circulation difference of the $500-\mathrm{mb}$ streamfunction between negative and positive $\mathrm{AO}$ winters (years listed in the figure caption for Fig. 6b). Next, the linear trend in the period 1980-2011 was removed from these years in order to isolate the interannual variability. The composite streamfunction anomalies in Fig. 6 b (i.e., without trend) reveal a circulation pattern very similar to that in Fig. 6a (i.e., with trend). The eddy streamfunction with the zonal mean removed (shading) delineates more clearly the Eurasian wave train. Because the negative AO phase was observed to become increasingly manifest since the late 1980s (Fig. 4d), its associated circulations may have intensified given the similarity between the AO pattern (Fig. 6b) and the decadal change (Fig. 6a). 


\section{c. Effect of SST warming}

The dry season of November-February occurs in most of the Northern Hemispheric subtropics because of the southward displacement of the Hadley cell as this enhances subsidence and drying around those latitudes. The Hadley cell is illustrated in Fig. 7a by the $250-\mathrm{mb}$ velocity potential (VP), the associated divergent winds, and the OLR. From the Sahel in Africa to the Indochina Peninsula and crossing Nepal, an upper-level convergence (indicative of air descent) is dominant over the stretch of high OLR values (indicative of less deep convective clouds and/or warm surface). In the southern Indian Ocean, the upper-level divergence signifies the ascending branch of the local Hadley circulation; this contributes to the formation of the dry season in Nepal and northern India. However, as is shown by the VP differences between the periods of 2001-10 and 19802000 (Fig. 7b), this divergent circulation has intensified during the past decade. Compared with Fig. 7a, the changing divergent circulation has strengthened the local Hadley circulation, which in turn has enhanced the descending branch over Nepal; this is supported by strong positive OLR anomalies being dominant over Nepal (suggestive of warm/dry anomalies). The descending branch of the local Hadley circulation over Nepal also coincides with that associated with the negative-phase AO (Fig. 5b).

The increased SST in the Indian Ocean, as is shown in Fig. 2a, has the potential to increase convective activity. Such a process is particularly effective over warm ocean surfaces because of the nonlinearity of the ClausiusClapeyron relationship (DiNezio et al. 2009). As can be inferred from the widespread negative anomalies of OLR over the tropical southern Indian Ocean (Fig. 7b), convective activity has likely enhanced over the last decade leading to upper-level divergence and northward transport of momentum. In view of the AO influence along with its decadal trend, we decided to conduct a regression analysis of the velocity potential and OLR with the AO index and then subtract them from the total fields (i.e., this linearly removes the interannual AO influence on the decadal variability). We then computed the linear trend of the VP and OLR with the AO signal removed (through linear regression). As is shown in Fig. 7c, the north-south contrast remains readily visible in such "AO-free" VP anomalies, yet the wave train pattern over the North Atlantic and European-Asian continents has weakened. The marked upper-level convergence over Nepal is weakened as well. This result suggests that the negative-phase $\mathrm{AO}$ wave train and the Indian Ocean warming have acted collectively to enhance subsidence over western Nepal, reducing its winter precipitation. Furthermore, the regional impact of the AO wave train explains the difference in precipitation and subsidence anomalies between eastern and western Nepal.

\section{d. Anthropogenic forcing}

In addition to the natural climate variability that results in drought, anthropogenic factors (greenhouse gases, aerosols, etc.) are surmised to play a role currently and more so in the future. One such player is that of aerosols-fine particles or liquid droplets in the air. The Indo-Gangetic Plains have very high concentrations of aerosols (Sarkar et al. 2006; Gautam et al. 2007). Winter aerosols in the Terai consist primarily of black carbon produced by fossil fuel combustion and biomass burning, while summer aerosols are mainly composed of dust transported from neighboring deserts (Collins et al. 2002). The impacts of increased aerosol loadings on the South Asian monsoon are still under debate. Some studies (Lau and Kim 2006; Meehl et al. 2008) propose that aerosols could heat up the Tibetan Plateau in the premonsoon season and subsequently enhance monsoonal rainfall, others (e.g., Ramanathan et al. 2005) have suggested that aerosols reduce the SST gradients of the Indian Ocean and thereby suppress monsoonal rainfall. As to the effect on the winter precipitation regime and thereby drought, the role of aerosols remains unclear and required further investigation.

We analyzed the 10 CMIP5 models (listed in Table 2) to investigate the possible role that anthropogenic forcings, like those of aerosols and greenhouse gases, might play in the observed decline in winter precipitation. Since the performance of different models is not uniform, we first evaluated how each model simulated the seasonal precipitation for western Nepal. By using the "natural" experiments and averaging for the 150-yr climatology, we normalized the monthly precipitation and examined the seasonal cycle. As is shown by the figure in the supplementary material, five of the models (CESM1, CanESM2, CCSM4, CNRM-CM5, and GFDL CM3) depicted a clear monsoon and low winter rainfall volume that was consistent with the GPCC observations; these five models were designated Group A. The remaining models (CSIRO, FGOALS, GISS-E2, IPSL-CM5, and NorESM1) produced a seasonal cycle that was inconsistent with the GPCC observations as they simulated multiple seasonal peaks in rainfall (see the figure in the supplementary material); these were designated Group B. We also included a criterion that the annual precipitation amount must be within $50 \%-150 \%$ of the observed. Consequently, NorESM1 was categorized in Group B as it produced an annual precipitation amount that was 3 times in excess 
(a) $\left(\mathrm{VP}, \mathrm{V}_{\mathrm{D}}\right)(250 \mathrm{mb})$, OLR : NDJF Climatology

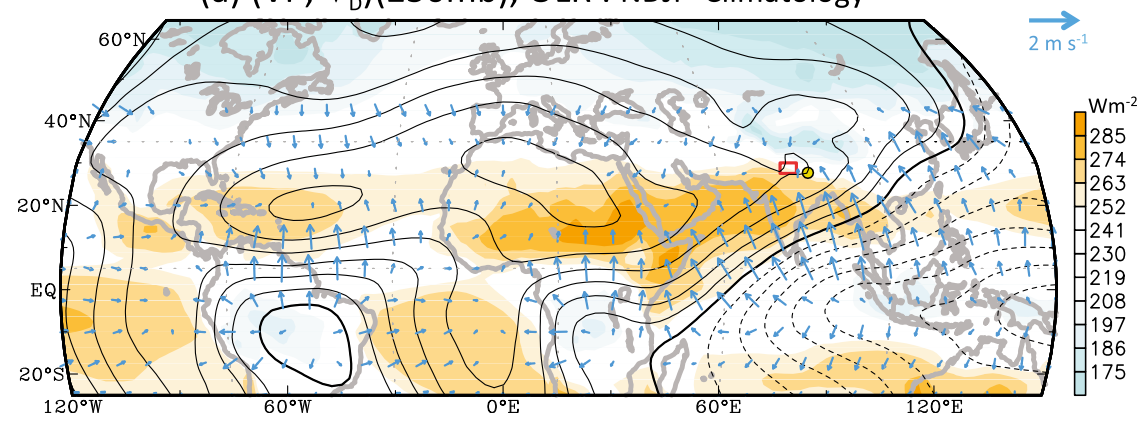

(b) $\Delta\left(V P, V_{D}\right)(250 m b), \Delta O L R: N D J F ~ 2001 / 2010-1980 / 2000$

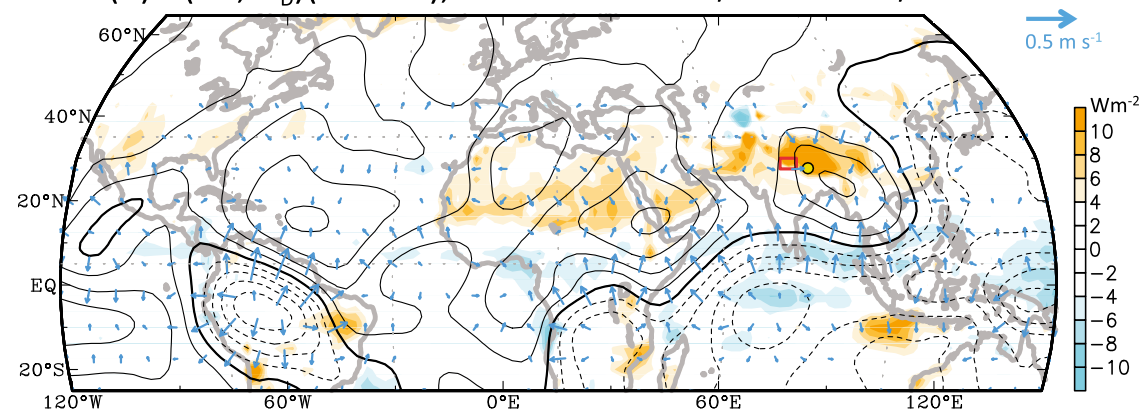

(c) $\left(\mathrm{VP}, \mathrm{V}_{\mathrm{D}}\right)(250 \mathrm{mb})$, OLR Trends: with the AO regressed out

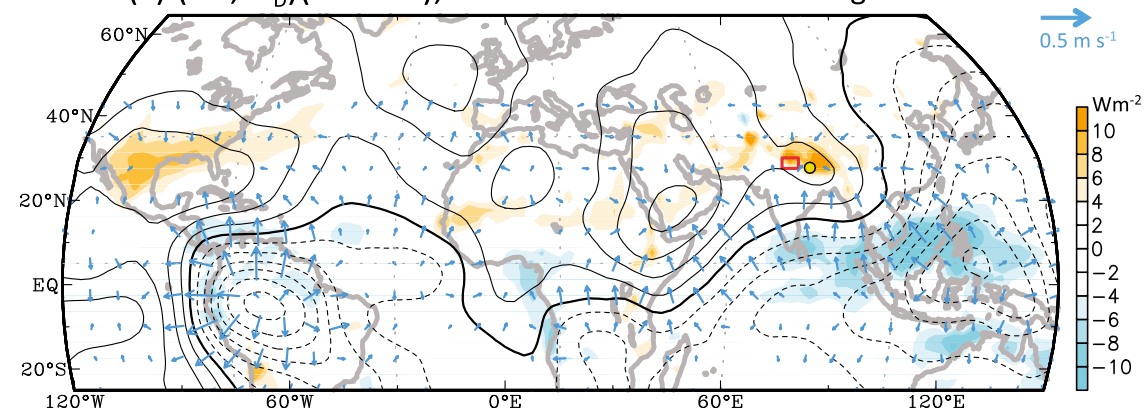

FIG. 7. (a) Climatological mean of the $250-\mathrm{mb}$ velocity potential (contours) and associated divergent winds (vectors), superimposed with OLR (shadings) for the winter season of November-February. (b) Differences in the three fields as in (a) between the periods 2001-10 and 1991-2000. (c) Linear trends of the three fields as in (a), but for the AO variability linearly removed through regression for the period of 1980-2011. Western Nepal is outlined as a red box; Nepal's capital city Kathmandu is indicated by a yellow dot.

of the observations, despite the fact that it captured the seasonality.

Next, we examined the winter precipitation evolution simulated by the ensemble of each model from the historical aerosol experiment (see section 2). Following Fig. 1, the November-February precipitation is shown in Fig. 8 overlaid with a 6 -yr running mean and a linear trend starting in 1991; here, the mean of simulated precipitation was adjusted to that of the GPCP. All Group A models indicate a decline in precipitation during the last 15 years (Fig. 8a), while Group B models depicted a mixture of trends (Fig. 8b). By comparison, precipitation change induced through the GHG experiment from Group A models (Fig. 9a) revealed consistent upward trends, while Group B models (Fig. 9b) showed either flat or downward trends. If one considers only Group A models (i.e., those consistent with observations), then the results in Figs. 8 and 9 indicate an induced decline in the precipitation in western Nepal with the addition of more aerosols, while the opposite is implied through increases in GHG. The GHG effect is presumably caused by the known nonlinear increase in the atmospheric moisture content associated with the tropospheric warming. 


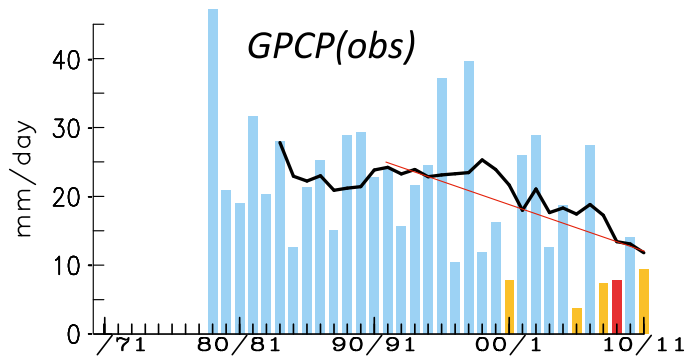

\section{Aerosols}

(a) Group-A models

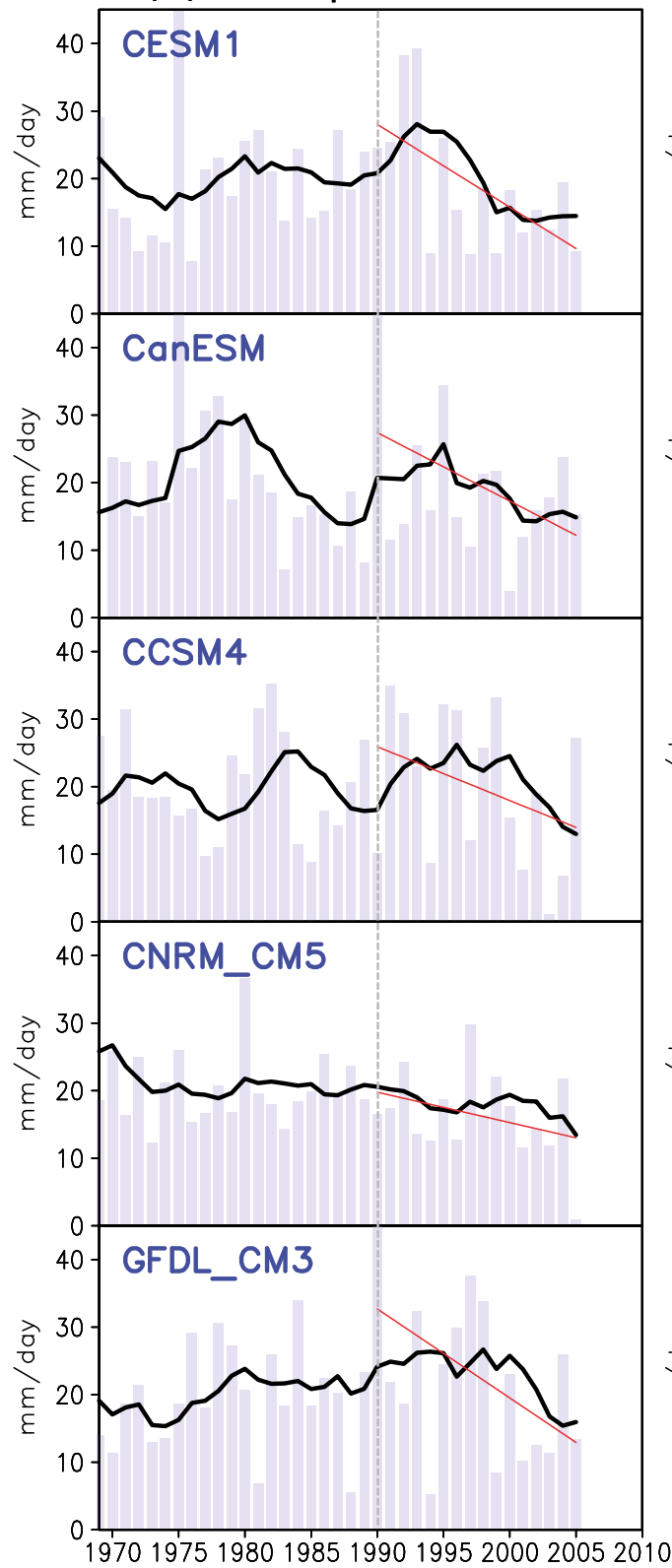

(b) Group-B models

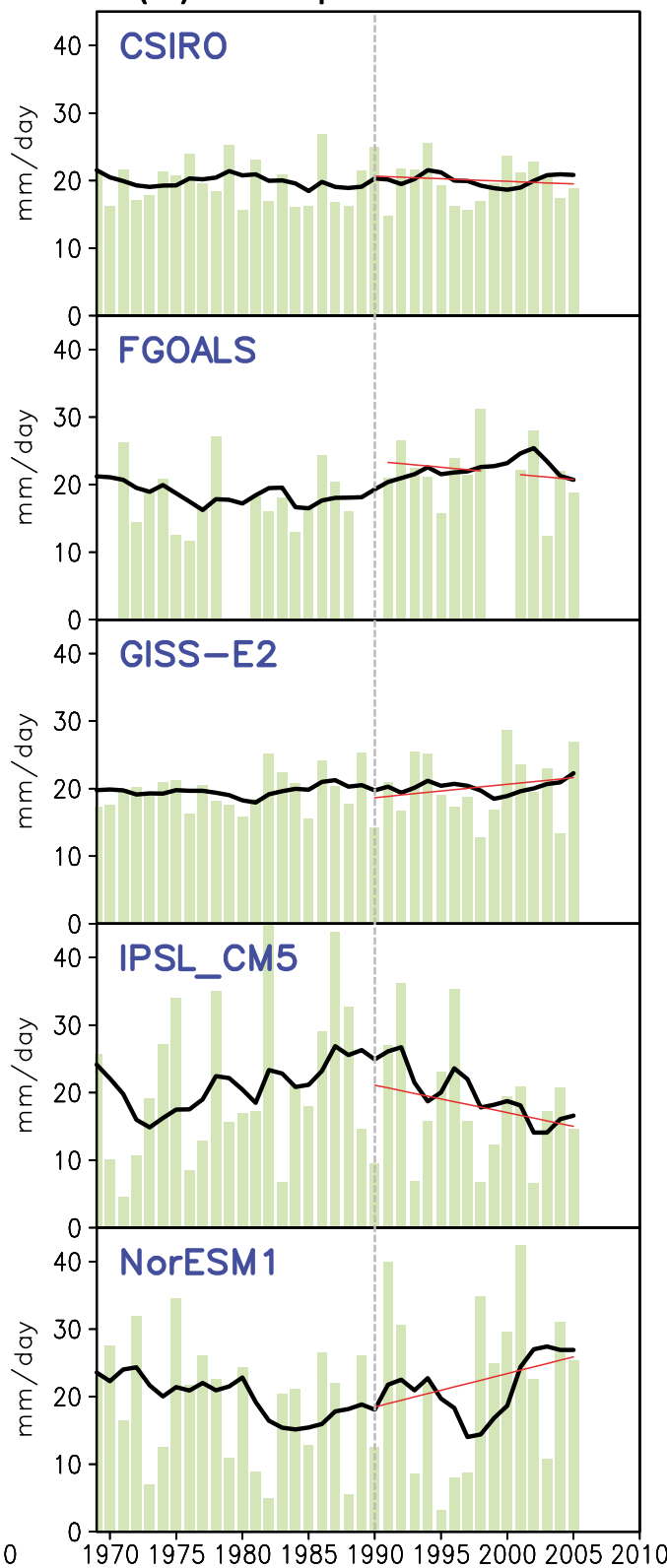

FIG. 8. Model precipitation in western Nepal during the November-February season from the CMIP5 historical aerosol experiment (histogram) for (a) Group A and (b) Group B models, overlaid with the 6-yr moving average (black line) and linear trend after 1990 (red line). The observed precipitation (GPCP), as in Fig. 1c, is plotted above (a) for reference. 


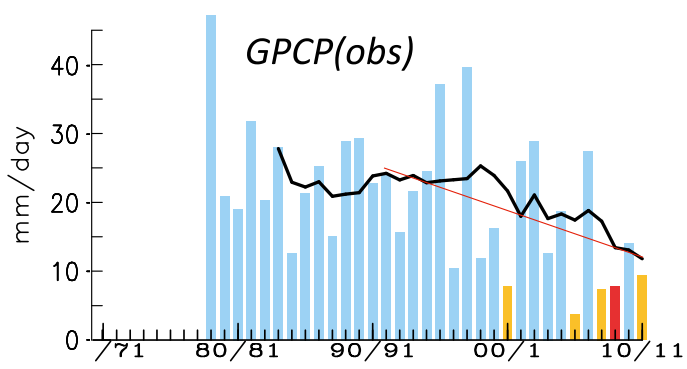

\section{GHG}

(a) Group-A models

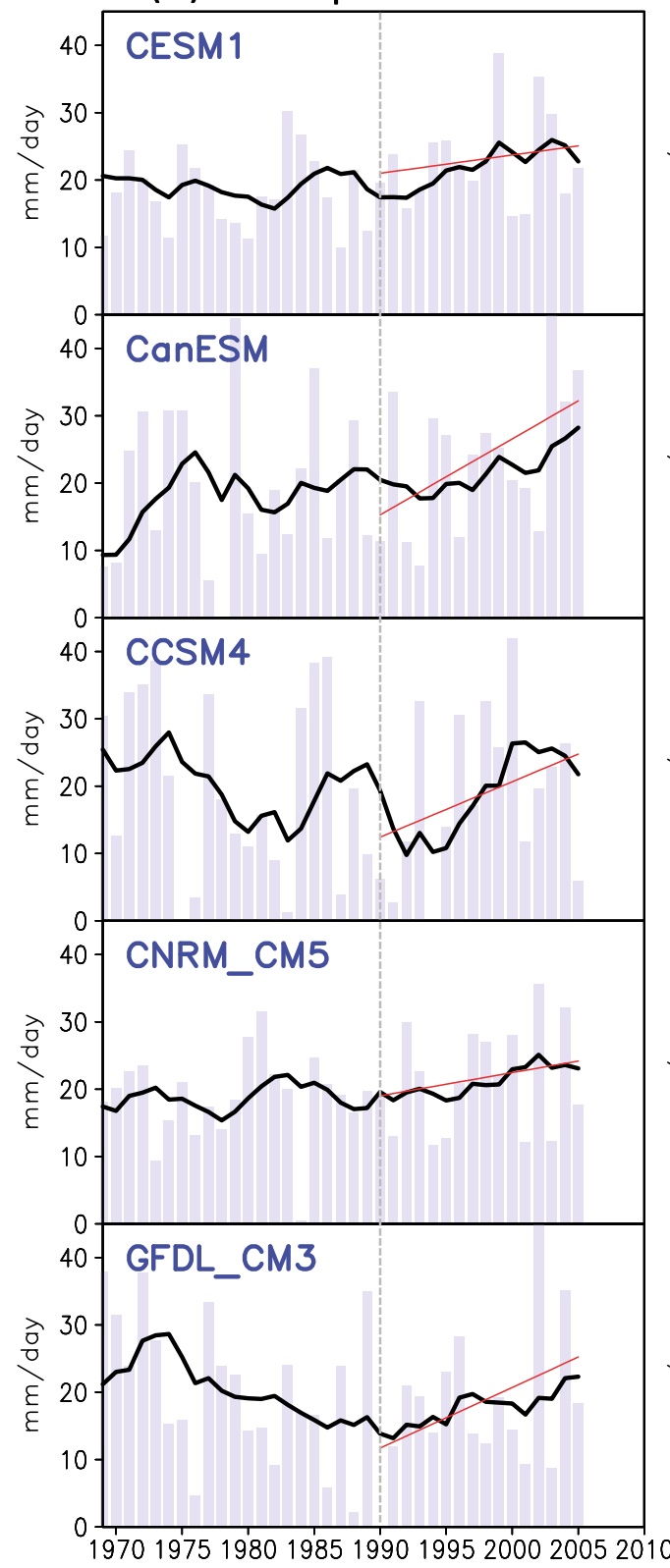

(b) Group-B models

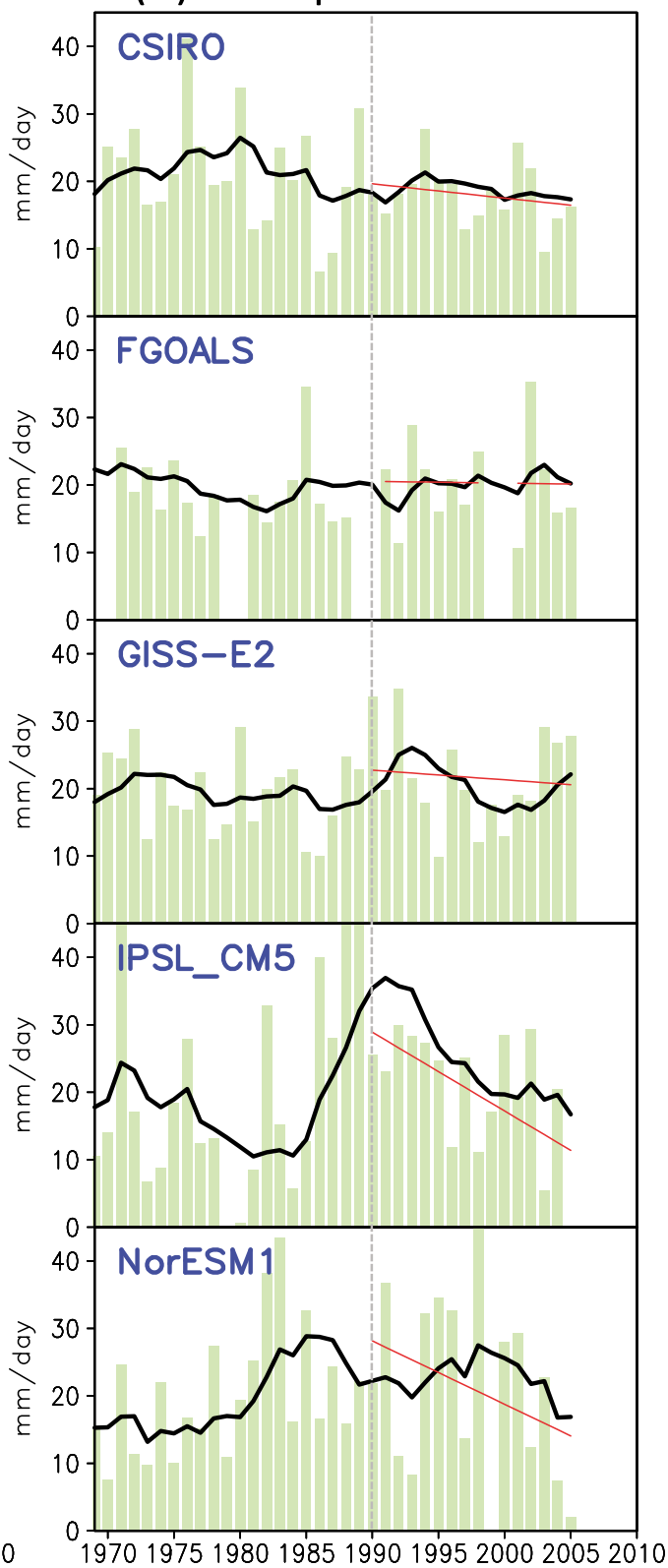

FIG. 9. As in Fig. 8, but for the historical GHG experiment. 
It has been shown (Chung and Ramanathan 2006; Lau and Kim 2006; Bollasina et al. 2008; Bollasina et al. 2011) that aerosols may influence precipitation in South Asia in various ways: (i) aerosols can produce many smaller cloud drops, and in so doing delay precipitation (Albrecht 1989); and (ii) since aerosols are predominantly emitted over land (and so can reduce the meridional thermal gradient across the Indian Ocean), in doing so, they tend to reduce the intensity of the Indian summer monsoon (Chung and Ramanathan 2006). As to how aerosols influence the drying trend of winter rainfall over Nepal, there has been only a modicum of research. However, of those that do exist, a couple of potential mechanisms are suggested: 1) Nepal is located in between northern India and western China, both of which have rapidly growing economies and exhibit excessive aerosol emissions. Therefore, certain degrees of locally induced effects with increased concentrations of aerosols likely inhibit precipitation. 2) Moreover, studies (Ackerley et al. 2011; Booth et al. 2012) have demonstrated that aerosols have affected climate variability over the Atlantic Ocean and as a consequence may alter climate teleconnections toward Nepal. As noted earlier, our analysis indicates that a remotely forced condition (i.e., the Arctic Oscillation) is active in playing a principal role. However, it is evident that multiple aerosol dynamics are being induced and so further analysis is needed to analyze and quantify the various local and remote contributions that aerosols are bringing about in influencing Nepal's winter rainfall.

\section{Concluding remarks}

Being in the relatively dry portion of this agrarian country, western Nepal is climatically more sensitive and less resilient to winter drought. The natural and possible anthropogenic causes of winter droughts in western Nepal were investigated through an examination of in situ, reanalysis, and modeling datasets. Precipitation analysis indicated that there has been a tendency toward more frequent and intense droughts in the dry season winter precipitation over the past decade. Evidence such as that observed through GRACE is another persuasive indicator of the persistent drought conditions that have occurred in western Nepal. Diagnostic analyses indicate that winter droughts in western Nepal are linked to at least three factors: 1) the AO interannual variation and its decadal trend toward negative phases creating a local mass-flux circulation with the descending branch over western Nepal, 2) SST warming in the southern Indian Ocean enhancing subsidence over much of Nepal, and 3) increased loadings of anthropogenic aerosols both locally and from surrounding countries.
Whether or not the AO tendency toward its negative phase will continue remains unclear, but it is rather more certain that the Indian Ocean will continue to warm as part of the global warming trend (Wang et al. 2013). The aerosol loading in the Indo-Gangetic Plain is expected to stabilize if not increase further (Lamarque et al. 2010). The implication is that even though the AO may reverse its trend in the future, the concurrence of a negative $\mathrm{AO}$ phase with the ongoing tendencies of the Indian Ocean warming and aerosol loading will likely heighten the suppression of rainfall, leading to stronger and/or more frequent droughts. It would be prudent to examine future climate simulations for the dry season climate for Nepal and northern India. Given the observations that winter precipitation has declined to near zero (Fig. 1b), while groundwater has hardly been replenished (Fig. 2b), management of western Nepal's water resources is critical.

The present analysis of CMIP5 simulations, as well as past studies, supports the supposition that aerosols, to a certain degree, are instrumental in contributing to the recent drying trend over Nepal. However, it was observed that there was considerable variance in individual CMIP5 models' abilities to capture the seasonal cycles of precipitation for western Nepal, and of those that did the precipitation time series show disparities albeit that they are consistent in indicating a steady decrease in the winter precipitation over western Nepal. It also remains questionable regarding whether and how well a climate model simulates the interaction between aerosol and clouds (e.g., Wang et al. 2012). On top of such uncertainties in the simulation of aerosol impact is the challenge of the relatively coarse resolution of CMIP5 models (at the scale of $100-200 \mathrm{~km}$ ) in simulating precipitation over steep and complex terrain such as that in Nepal; it is anticipated that the planned higherresolution version of the CESM1 will overcome this obstacle.

Acknowledgments. This study was supported by the United States Agency for International Development Grant EEM-A-00-10-00001 and the NASA Grant NNX13AC37G. J.-H. Yoon is supported by the Earth System Modeling program of CESD/BER/DOE. PNNL is operated for the United States Department of Energy by Battelle Memorial Institute under Contract DEAC06-76RLO1830.

\section{REFERENCES}

Ackerley, D., B. B. B. Booth, S. H. E. Knight, E. J. Highwood, D. J. Frame, M. R. Allen, and D. P. Rowell, 2011: Sensitivity of twentieth-century Sahel rainfall to sulfate aerosol and $\mathrm{CO}_{2}$ forcing. J. Climate, 24, 4999-5014. 
Adler, R. F., and Coauthors, 2003: The version-2 Global Precipitation Climatology Project (GPCP) monthly precipitation analysis (1979-present). J. Hydrometeor., 4, 1147-1167.

Albrecht, B. A., 1989: Aerosols, cloud microphysics, and fractional cloudiness. Science, 245, 1227-1230.

Bamzai, A. S., and J. Shukla, 1999: Relation between Eurasian snow cover, snow depth, and the Indian summer monsoon: An observational study. J. Climate, 12, 3117-3132.

Barlow, M., H. Cullen, and B. Lyon, 2002: Drought in central and southwest Asia: La Niña, the warm pool, and Indian Ocean precipitation. J. Climate, 15, 697-700.

_ - M. Wheeler, B. Lyon, and H. Cullen, 2005: Modulation of daily precipitation over southwest Asia by the Madden-Julian oscillation. Mon. Wea. Rev., 133, 3579-3594.

Bollasina, M. A., S. Nigam, and K. M. Lau, 2008: Absorbing aerosols and summer monsoon evolution over South Asia: An observational portrayal. J. Climate, 21, 3221-3239.

_- Y. Ming, and V. Ramaswamy, 2011: Anthropogenic aerosols and the weakening of the South Asian summer monsoon. Science, 334, 502-505.

Booth, B. B., N. J. Dunstone, P. R. Halloran, T. Andrews, and N. Bellouin, 2012: Aerosols implicated as a prime driver of twentieth-century North Atlantic climate variability. Nature, 484, 228-232.

Choi, D.-H., J.-S. Kug, W.-T. Kwon, F.-F. Jin, H.-J. Baek, and S.-K. Min, 2010: Arctic Oscillation responses to greenhouse warming and role of synoptic eddy feedback. J. Geophys. Res., 115, D17103, doi:10.1029/2010JD014160.

Chung, C. E., and V. Ramanathan, 2006: Weakening of North Indian SST gradients and the monsoon rainfall in India and the Sahel. J. Climate, 19, 2036-2045.

Collins, W. D., P. J. Rasch, B. E. Eaton, D. W. Fillmore, J. T. Kiehl, C. T. Beck, and C. S. Zender, 2002: Simulation of aerosol distributions and radiative forcing for INDOEX: Regional climate impacts. J. Geophys. Res., 107, 8028, doi:10.1029/ 2000JD000032.

Delworth, T. L., and K. W. Dixon, 2000: Implications of the recent trend in the Arctic/North Atlantic Oscillation for the North Atlantic thermohaline circulation. J. Climate, 13, 3721-3727.

DiNezio, P. N., A. C. Clement, G. A. Vecchi, B. J. Soden, B. P. Kirtman, and S.-K. Lee, 2009: Climate response of the equatorial Pacific to global warming. J. Climate, 22, 4873 4892.

Ding, Q., and B. Wang, 2007: Intraseasonal teleconnection between the summer Eurasian wave train and the Indian monsoon. J. Climate, 20, 3751-3767.

Famiglietti, J. S., and Coauthors, 2011: Satellites measure recent rates of groundwater depletion in California's Central Valley. Geophys. Res. Lett., 38, L03403, doi:10.1029/2010GL046442.

Fasullo, J., and P. J. Webster, 2003: A hydrological definition of Indian monsoon onset and withdrawal. J. Climate, 16, 32003211.

Feldstein, S. B., 2002: The recent trend and variance increase of the annular mode. J. Climate, 15, 88-94.

Ganguly, D., P. J. Rasch, H. Wang, and J.-H. Yoon, 2012: Climate response of the South Asian monsoon system to anthropogenic aerosols. J. Geophys. Res., 117, D13209, doi:10.1029/ 2012JD017508.

Gautam, R., N. C. Hsu, M. Kafatos, and S.-C. Tsay, 2007: Influences of winter haze on fog/low cloud over the IndoGangetic plains. J. Geophys. Res., 112, D05207, doi:10.1029/ 2005JD007036.
Ghosh, S., V. Luniya, and A. Gupta, 2009: Trend analysis of Indian summer monsoon rainfall at different spatial scales. Atmos. Sci. Lett., 10, 285-290.

Hoerling, M., and A. Kumar, 2003: The perfect ocean for drought. Science, 299, 691-694.

Hoskins, B. J., and T. Ambrizzi, 1993: Rossby wave propagation on a realistic longitudinally varying flow. J. Atmos. Sci., 50,16611671.

Janowiak, J. E., and P. Xie, 1999: CAMS-OPI: A global satelliterain gauge merged product for real-time precipitation monitoring applications. J. Climate, 12, 3335-3342.

Lamarque, J., and Coauthors, 2010: Historical (1850-2000) gridded anthropogenic and biomass burning emissions of reactive gases and aerosols: Methodology and application. Atmos. Chem. Phys., 10, 7017-7039.

Lang, T. J., and A. P. Barros, 2004: Winter storms in the central Himalayas. J. Meteor. Soc. Japan, 82, 829-844.

Lau, K.-M., and K.-M. Kim, 2006: Observational relationships between aerosol and Asian monsoon rainfall, and circulation. Geophys. Res. Lett., 33, L21810, doi:10.1029/2006GL027546.

Lau, N.-C., and M. J. Nath, 1991: Variability of the baroclinic and barotropic transient eddy forcing associated with monthly changes in the midlatitude storm tracks. J. Atmos. Sci., 48, 2589-2613.

Li, J., R. Yu, and T. Zhou, 2008: Teleconnection between NAO and climate downstream of the Tibetan Plateau. J. Climate, 21, 4680-4690.

Meehl, G. A., J. M. Arblaster, and W. D. Collins, 2008: Effects of black carbon aerosols on the Indian monsoon. J. Climate, 21, 2869-2882.

Mitchell, T. D., and P. D. Jones, 2005: An improved method of constructing a database of monthly climate observations and associated high-resolution grids. Int. J. Climatol., 25, 693-712.

Nakamura, H., T. Miyasaka, Y. Kosaka, K. Takaya, and M. Honda, 2010: Northern Hemisphere extratropical tropospheric planetary waves and their low-frequency variability: Their vertical structure and interaction with transient eddies and surface thermal contrasts. Climate Dynamics: Why Does Climate Vary?, Geophys. Monogr., Vol. 189, Amer. Geophys. Union, 149-180.

Plumb, R. A., 1985: On the three-dimensional propagation of stationary waves. J. Atmos. Sci., 42, 217-229.

Ramanathan, V., and Coauthors, 2005: Atmospheric brown clouds: Impacts on South Asian climate and hydrological cycle. Proc. Natl. Acad. Sci. USA, 102, 5326-5333.

Rees, H. G., and D. N. Collins, 2006: Regional differences in response of flow in glacier-fed Himalayan rivers to climatic warming. Hydrol. Processes, 20, 2157-2169.

Rienecker, M. M., and Coauthors, 2011: MERRA: NASA's Modern-Era Retrospective Analysis for Research and Applications. J. Climate, 24, 3624-3648.

Rodell, M., I. Velicogna, and J. S. Famiglietti, 2009: Satellite-based estimates of groundwater depletion in India. Nature, 460, 999 1002.

Ropelewski, C. F., and M. S. Halpert, 1987: Global and regional scale precipitation patterns associated with the El Niño/ Southern Oscillation. Mon. Wea. Rev., 115, 1606-1626.

Saha, K., 2010: Monsoon over southern Asia. Tropical Circulation Systems and Monsoons, Springer, 89-122.

Sarkar, S., R. Chokngamwong, G. Cervone, R. P. Singh, and M. Kafatos, 2006: Variability of aerosol optical depth and aerosol forcing over India. Adv. Space Res., 37, 2153-2159.

Shrestha, A. B., C. P. Wake, J. E. Dobb, P. A. Mayewski, S. I. Whitlow, G. R. Carmichael, and M. Ferm, 2000: Seasonal 
variations in aerosol concentrations and compositions in the Nepal Himalaya. Atmos. Environ., 34, 3349-3363.

Smith, T. M., and R. W. Reynolds, 2003: Extended reconstruction of global sea surface temperatures based on COADS data (1854-1997). J. Climate, 16, 1495-1510.

Takaya, K., and H. Nakamura, 2001: A formulation of a phaseindependent wave-activity flux for stationary and migratory quasigeostrophic eddies on a zonally varying basic flow. J. Atmos. Sci., 58, 608-627.

Taylor, K. E., R. J. Stouffer, and G. A. Meehl, 2012: An overview of CMIP5 and the experiment design. Bull. Amer. Meteor. Soc., 93, 485-498.

Wang, M., and Coauthors, 2012: Constraining cloud lifetime effects of aerosols using A-Train satellite observations. Geophys. Res. Lett., 39, L15709, doi:10.1029/2012GL052204.
Wang, S.-Y., and R. Gillies, 2013: Influence of the Pacific quasidecadal oscillation on the monsoon precipitation in Nepal. Climate Dyn., 40, 95-107.

_, R. R. Gillies, L. E. Hipps, and J. Jin, 2011: A transition-phase teleconnection of the Pacific quasi-decadal oscillation. Climate Dyn., 36, 681-693.

- B. M. Buckley, J. H. Yoon, and B. Fosu, 2013: Intensification of premonsoon tropical cyclones in the Bay of Bengal and its impacts on Myanmar. J. Geophys. Res., 118, 4373-4384, doi:10.1002/jgrd.50396.

Wang, Y., and T. Yasunari, 1994: A diagnostic analysis of the wave train propagating from high-latitudes to low-latitudes in early summer. J. Meteor. Soc. Japan, 72, 269-279.

Yoon, J.-H., and N. Zeng, 2010: An Atlantic influence on Amazon rainfall. Climate Dyn., 34, 249-264. 